\title{
Effects of chronic low-dose radiation on the common reed within the Chernobyl accident Exclusion Zone
}

\author{
M.A. Nurgudin, N.L. Shevtsova and D.I. Gudkov \\ Department of Radioecology, Institute of Hydrobiology of the National Academy of Sciences \\ of Ukraine, Geroyev Stalingrada Ave. 12, UA-04210 Kiev, Ukraine
}

\begin{abstract}
The results of the analyses of plant production and parasitic resistance of common reed (Phragmites australis (Cav.) Trin. ex. Steud) from water bodies within the Chernobyl accident exclusion zone are represented. The heavy damage of common reed by the ergot (Claviceps purpurea (Fr.) Tul.) (up to 50\%) from water bodies of the left-bank flood lands of the Pripyat River, which is the most contaminated region of the Chernobyl NPP exclusion zone, has been investigated. Deviations in morphological indexes of reproductive organs of common reed from water bodies of right- and left-bank flood lands of the Pripyat River within 10-km exclusion zone are registered. There are: decrease of panicle width, length and flowers number at inflorescence; differences in seed shape and color. The direct correlation between the absorbed dose rate for higher aquatic plants and plant productivity indexes as well as damage events of common reed by the ergot is proved. The parasitic resistance of common reed from water bodies within Chernobyl accident exclusion zone are decreased according to the increase of absorbed dose rate as well.
\end{abstract}

\section{INTRODUCTION}

The investigation of biological effects of long-term irradiation on non-human biota inhabiting the radioactive contaminated territories, has a theoretical and applied importance for ecological hazard understanding, associated with changing of environmental radioactivity state due to human activity. The territory of the Chernobyl accident Exclusion Zone gives a unique opportunity to examine state of flora and fauna in conditions of man-made radioactive anomaly. After the Chernobyl NPP accident within the inner (10-km) Exclusion Zone the numerous of morphological anomalies, such as juvenility or sterility of reproductive organs, excessive bifurcation, decrease of parasitical resistance etc. in terrestrial plants are registered $[1,2]$. Since 2000 the increase of common read damage by gall-producing arthropods (mainly by mites of Tarsonemidae family) is observed [3]. The main purposes of our research were to assess the abnormalities rate of common reed's reproductive organs to reveal possible morphological changes and to analyze the changes of stability of the common reed to the ergot Claviceps purpurea (Fr.) Tul. (parasitic fungi), depending on radiation exposure in water bodies with different levels of radioactive contamination within the Chernobyl accident Exclusion Zone.

\section{MATERIALS AND METHODS}

Common reed (Phragmites australis (Cav.) Trin. ex. Steud) belongs to the graminoid family of the monocotyledonous class of the seed plants. It is a perennial plant that clones by rootstocks and reproduces by seeds. Blossom cluster of the reed corresponds as large, dense, more or less sprawling panicle with plum colored fuzz. Panicle has $20-50 \mathrm{~cm}$ length and $10-20 \mathrm{~cm}$ width. Flowers number of a low-level blossom cluster varies from 3 to 7; inferior flower is staminal and others are teleianthous [4].

The reed's panicles were sampling during September-October 2006 on water bodies within the range of 10-km Chernobyl NPP accident inner exclusion zone - Azbuchin Lake, Yanovsky Crawl, Chernobyl NPP cooling pond, that are located on the right bank floodplain of the Pripyat River, and 
also in Dalekoe-1 Lake and Glubokoe Lake that are located in range of left-bank dammed floodplain of the Pripyat River.

Length and width of the reed panicle, number of the flowers of a low-level blossom cluster, length, width, colour, bulk and mass of the seeds were estimated in accordance with the generally accepted botanical methods [5]. We studied potential seed production (average number of seeds for the generative spear); effective seed output (ESO) - number of viable for the generative spear; panicle sterility ratio (PSR) - percentage of sterile flowers of the generative spear and parasitic fungi lesion ratio (PFLR) percentage of ergot sclerotium in the generative spears. We used the next formula for calculation of the panicle sterility ratio: $\mathrm{PSP}=100-\mathrm{ESO}-\mathrm{PFLR}$. Panicle sterility ratio in the formula is used on account of the fact that conidium of the parasitic fungi intergrows only in the ovary and after that mycelium compacts and turns sclerotium.

\section{RESULTS AND CONCLUSIONS}

Average absorbed dose rate was found from 0.022 to $0.120 \mathrm{~Gy} \mathrm{year}^{-1}$ for the reed from littoral and sublittoral zone of investigated water bodies: Chernobyl NPP cooling pond ( $\left.0.022 \mathrm{~Gy}_{\text {year }}{ }^{-1}\right)$; Yanovsky Crawl (0.037 Gy year ${ }^{-1}$ ); Azbuchin Lake (0.046 Gy year ${ }^{-1}$ ); Dalekoe-1 Lake (0.053 Gy year ${ }^{-1}$ ) and Glubokoe Lake $\left(0.120 \mathrm{~Gy}_{\text {year }}{ }^{-1}\right)$. Maximal rate of the absorbed dose was found for the lakes of the left-bank dammed floodplain of the Pripyat River, which are the most radioactive contaminated water bodies of the Exclusion Zone.

Analysis of the morphometric characteristics of the common reed panicles displays certain deviation connected with reed growth location (Table 1).

Table 1. Morphometric characteristics of the common reed panicles sampled within the range of the Chernobyl Exclusion Zone.

\begin{tabular}{|l|c|c|c|c|}
\hline Water body & $\begin{array}{c}\text { Number of } \\
\text { investigated } \\
\text { panicles }\end{array}$ & $\begin{array}{c}\text { Average length of } \\
\text { the panicle, cm }\end{array}$ & $\begin{array}{c}\text { Average width of } \\
\text { the panicle, cm }\end{array}$ & $\begin{array}{c}\text { Number of } \\
\text { flowers of low-level } \\
\text { blossom cluster }\end{array}$ \\
\hline Cooling pond & 18 & $28.7 \pm 1.4$ & $5.4 \pm 0.2$ & $3-4$ \\
\hline Yanovsky Crawl & 16 & $30.0 \pm 1.5$ & $4.8 \pm 0.2$ & $3-4$ \\
\hline Azbuchin Lake & 22 & $26.4 \pm 1.3$ & $6.1 \pm 0.3$ & $4-6$ \\
\hline Dalekoe-1 Lake & 15 & $23.7 \pm 1.1$ & $3.1 \pm 0.1$ & $2-3$ \\
\hline Glubokoe Lake & 16 & $19.9 \pm 0.9$ & $2.7 \pm 0.1$ & $2-3$ \\
\hline
\end{tabular}

It is known that common reed's panicles length and width vary from 20 to $50 \mathrm{~cm}$ and 10-25 accordingly and number of a low-level blossom cluster also vary from 3 to 7 . Thus average morphometric characteristics of the reed's panicles sampled from the water bodies within the Exclusion Zone refer to minimal of the normal reed plant but average width is lesser than normal reed plant has. Furthermore the number of flowers of a low-level blossom cluster is more often 2 then 3 for the common reed sampled from the water bodies within the Exclusion Zone.

Correlation analysis showed direct dependence between variation of the reed panicle characteristics variation and absorbed dose rate of the ionizing radiation. Thus the Pirson correlation coefficient for the number of flowers of a low-level blossom cluster and absorbed dose rate of the ionizing radiation was 0.89 and error coefficient was 0.068 .

Essential divergence for morphometric characteristics of the common reed seeds was not discovered. But patience should be paid to the shape and colour of the reed's seeds sampled from lakes Dalekoe-1 and Glubokoe that have highest radionuclide contamination within the range of the Chernobyl Exclusion Zone (Table 2). Such abnormalities could be interpreted as radiomorphoses, which also were registered for some species of cultural graminoid, for example for fall wheat [2]. 
Table 2. Morphometric characteristics of the common reed's seeds, sampled within the range of the Chernobyl Exclusion Zone.

\begin{tabular}{|c|c|c|c|c|c|c|c|}
\hline \multirow[b]{2}{*}{ Water body } & \multirow[b]{2}{*}{$\begin{array}{l}\text { Number } \\
\text { of seeds }\end{array}$} & \multicolumn{4}{|c|}{ Average morphometric characteristics } & \multirow[b]{2}{*}{ Shape } & \multirow[b]{2}{*}{ Color } \\
\hline & & $\begin{array}{c}\text { length, } \\
\text { mm }\end{array}$ & $\begin{array}{l}\text { width, } \\
\mathrm{mm}\end{array}$ & $\begin{array}{c}\text { volume, } \\
\mathrm{mm}^{3}\end{array}$ & $\begin{array}{c}\text { mass, } \\
\mathrm{mg}\end{array}$ & & \\
\hline $\begin{array}{l}\text { Chernobyl NPP } \\
\text { cooling pond }\end{array}$ & 32765 & 3.2 & 0.9 & 1.5 & 0.13 & pillow-like smooth & sandy \\
\hline Yanovsky Crawl & 35478 & 2.9 & 0.9 & 1.4 & 0.10 & pear-shaped, hilly & sandy \\
\hline Azbuchin Lake & 36574 & 2.9 & 1.1 & 1.9 & 0.11 & pillow-like smooth & brown \\
\hline Dalekoe-1 Lake & 32879 & 2.9 & 1.0 & 1.5 & 0.12 & tear-shaped, plicate & brown \\
\hline Glubokoe Lake & 28764 & 2.9 & 1.0 & 1.5 & 0.11 & tear-shaped, plicate & ark bror \\
\hline
\end{tabular}

Also parameters of the common reed seed productivity and parasitic fungi (Claviceps purpurea) lesions ratio was studied (Table 3 ).

Table 3. Average parameters of seed productivity and parasitic fungi (Claviceps purpurea) lesions ratio in the common reed within the range of the Chernobyl Exclusion Zone.

\begin{tabular}{|l|c|c|c|c|}
\hline Water body & $\begin{array}{c}\text { Potential seed } \\
\text { production, seeds } \\
\text { per panicle }\end{array}$ & $\begin{array}{c}\text { Effective seed } \\
\text { output, \% }\end{array}$ & $\begin{array}{c}\text { Panicle sterility } \\
\text { ratio, \% }\end{array}$ & $\begin{array}{c}\text { Parasitic fungi } \\
\text { lesions ratio, \% }\end{array}$ \\
\hline $\begin{array}{l}\text { Chernobyl NPP } \\
\text { cooling pond }\end{array}$ & $4200 \pm 28$ & $41.8 \pm 0.1$ & $53.1 \pm 0.1$ & $5.1 \pm 0.1$ \\
\hline Yanovsky Crawl & $4130 \pm 25$ & $32.0 \pm 0.2$ & $64.1 \pm 0.2$ & $3.9 \pm 0.1$ \\
\hline Azbuchin Lake & $5527 \pm 32$ & $69.9 \pm 0.1$ & $29.4 \pm 0.1$ & $0.7 \pm 0.1$ \\
\hline Dalekoe-1 Lake & $2572 \pm 12$ & $6.8 \pm 0.1$ & $71.7 \pm 0.1$ & $21.5 \pm 0.1$ \\
\hline Glubokoe Lake & $2116 \pm 10$ & $6.0 \pm 0.3$ & $47.5 \pm 0.1$ & $46.5 \pm 0.1$ \\
\hline
\end{tabular}

The increase of the parasitic fungi lesions ratio simultaneous the enhancement of absorbed dose rate of ionizing radiation, which may conclude of chronic low-dose radiation influence upon the populations of the common reed within the Chernobyl Exclusion Zone, was determined. At that the Pirson correlation coefficient for the parasitic fungi lesions ratio and absorbed dose rate of ionizing radiation was 0.913 and error coefficient was 0.030 .

Relation of potential seed production and effective seed output is one of the significant parameter characterizing rate of reproductive performance suppression of plant. Thus for the cultural cereal explorers observed complete or partial sterility $[1,2]$ but for the common reed we found that panicle sterility ratio does not exceed 72 percents. In normal case 1 panicle produces about 5,000 viable seeds [4] but in our case even potential seed production was much lesser.

The Pirson correlation coefficient for the effective seed output and parasitic fungi lesions ratio was 0.814 and error coefficient was 0.047 which confirms parasitic fungi lesions ratio influence on seed production of the plant.

Performed studies indicate the existence of authentic morphometric and morphological abnormalities of reproductive organs of the common reed within the Chernobyl Exclusion Zone. The most typical abnormalities are decreasing of average reed panicle length and width; decreasing of the number of flowers of a low-level blossom cluster and also modification of the shape and colour of the seeds in comparison with standard parameters for the common reed of Europe's middle latitude.

The influence of parasitic fungi (Claviceps purpurea) lesions on the seed production of the common reed was determined. The positive correlation between registered abnormalities and parasitic fungi lesions of the common reed with levels of radiation exposure on plants, sampled from the water bodies within the Chernobyl NPP accident exclusion zone was registered.

Registered high level of parasitic fungi lesions ratio for the common reed plants sampled from the lakes of the left dammed floodplain of the Pripyat River, which are the most radioactive contaminated 
water bodies of the Chernobyl accident Exclusion Zone. Above mentioned phenomenon may testify upon the decreasing of the parasitical stability of the common reed under impact of chronic low-dose irradiation.

\section{References}

[1] Grodzinsky, D.M., Kolomiets, K.D. and Kutlakhmedov, Yu.A. et al., 1991. Anthropogenic radioactive anomaly and plants, Lybid', Kiev (Rus).

[2] Grodzinsky, D.M., Kolomiets, K.D. and Burdenyuk, O.D. 2000. Mutagenesis of plants in the Exclusion Zone. Bulletin of the Ecological Condition of the Exclusion Zone and the Zone of Absolute Resettlement, 16: 50-54 (Ukr).

[3] Gudkov, D.I., Uzhevskaya, C.F. and Nazarov, A.B. et al., 2006. Lesion in common reed by gallproducing arthropods in water bodies of the Chernobyl NPP exclusion zone. Hydrobiological Journal, 1: 82-88.

[4] Dubina, D.V., Stoyko, S.M. and Sytnik, K.M. et al., 1993. Macrophytes - indicators of environmental changes. Naukova Dumka. Kiev (Rus).

[5] Demidovskaya, L.F. and Kirichenko, R.A., 1964. Morphological characteristics of the common reed. Proceedings of the Institute of Botany of the Kazakhstan Academy of Sciences, 19: 109-135.

[6] Gudkov, D., Shevtsova, N. and Dzyubenko, O. et al., 2006. Dose rates and effects of chronic environmental radiation on hydrobionts within the Chernobyl exclusion zone. - Radiation risk estimation in normal and emergency situations. - Springer. 2006. - P. 69-76. 